\title{
Karyotype and Nuclear DNA Content of Six Species of Astragalus (Leguminosae)
}

\author{
L. P. Dopchiz ${ }^{1,2}$, E. Gómez-Sosa ${ }^{3}$ and L. Poggio ${ }^{1,2}$ \\ 'Instituto Fitotécnico de Sta. Catalina (FCAF, UNLP)-Centro de Investigaciones Genéticas \\ (CONICET-UNLP-CIC), C.C. 4, 1836 Llavallol, Buenos Aires, Argentina \\ ${ }^{2}$ Departamento de Cs. Biológicas (FCEN, UBA), 1428, Buenos Aires, Argentina \\ ${ }^{3}$ Instituto de Botánica Darwinion (Acad. Nac. Cs. Ex. Fis. and Nat.-CONICET), \\ C.C. 22, 1642, San Isidro, Argentina
}

Accepted July 17, 1995

The genus Astragalus L. (Leguminosae-Galegeae) is remarkably wide-spread, with about 2500 species worldwide except for Australia and New Zealand. The basic numbers reported for the genus Astragalus are $\mathrm{x}=6,8,11,12,13,14$ and 15 (Ledingham and Fahselt 1964, Spellenberg 1976, Ashraf and Gohil 1988). In Old World species, the basic number $x=8$ and polyploidy are frequent. The other basic numbers are common in New World species but polyploidy here is rare (Ledingham 1960, Ledingham and Fahselt 1964, Ledingham and Pepper 1973, Spellenberg 1976, Daviña and Gómez-Sosa 1993). Several hypothesis have been advanced to explain the origin of the different basic numbers in Astragalus (reviewed in Spellenberg 1976). The preponderance of species with $x=8$ found also in related genera suggests that the direction of chromosome change has been from $x=8$ to the others $(x=11$ to $x=15$ ), perhaps through polyploidy, followed by loss of a few chromosomes. The basic number of $x=6$ was reported for a single Himalayan species by Ashraf and Gohil (1988). These authors suggest that $x=6$ was derived from $x=8$ by aneuploid loss of chromosomes. Evolutionary relationship within the genus inferred from nucleotide sequence variation in nuclear ribosomal DNA also argues that the direction of change appears to be from $x=8$ to higher numbers (Wojciechowski et al. 1993). These authors suggest that if the New World aneuploid series arose by descending aneuploidy from a tetraploid $x=16$ or by both ascending and descending aneuploidy from an ancestor $x=12$, remains uncertain.

Karyotype characteristics can be a useful guide to assessing taxonomic relationships and evolutionary trends. Most cytological information on South American Astragalus has been restricted to chromosome numbers with a few accurate descriptions of other karyotypic characteristics (Ledingham and Pepper 1973, Daviña and Gómez-Sosa 1993).

The genus Astragalus distributed along the South American Andes from Ecuador to Chile and Argentina with approximately 100 valid species (Gómez-Sosa 1979). About 70 of these species are found in Argentina from Jujuy Province to Tierra del Fuego Province. The six species studied here occur in the phytogeographical region of Northern Patagonia. Four are Argentinian endemics, while $A$. pehuenches Niederl. and $A$. cruckshanksii (Hook. \& Arn.) Griseb. also occur in the Chilean area (Gómez-Sosa 1984, 1994).

The aim of this research was to cytologically characterize the species $A$. cruckshanksii, $A$. illinii I. M. Johnst., $A$. moyanoi Speg., $A$. neuquenensis Gómez-Sosa, $A$. palenae (Phil.) Reiche var. grandiflora Speg. and $A$. pehuenches, and to clarify interspecific relationships.

Material and methods

The origin of the species studied is shown in Table 1. Voucher specimens are deposited in 
Table 1. Origin of the studied materials

\begin{tabular}{lcl}
\hline Species & Voucher number & Places of collection \\
\hline A. pehuenches & G-S 395 & Argentina, Chubut, Dpto. Telsen \\
A. palenae var. grandifiora & G-S 400 & Argentina, Chubut, Dpto. Gastre. \\
& G-S 384 & Argentina, Neuquén, Dpto. Lacar. \\
A. moyanoi & G-S 393 & Argentina, Neuquén, Dpto. Lacar. \\
& G-S 386 & Argentina, Neuquén, Dpto. Lacar. \\
A. neuquenensis & G-S 387 & Argentina, Neuquén, Dpto. Lacar. \\
A. cruckshanksii & G-S 390 & Argentina, Neuquén, Dpto. Catán-Lil. \\
A. illinii & G-S 389 & Argentina, Neuquén, Dpto. Catán-Lil. \\
\hline
\end{tabular}

$\mathrm{G}-\mathrm{S}=$ = Gómez-Sosa

the Herbarium of Instituto Darwinion (SI) (Argentina).

Karyotype analysis: Root tips of germinating seeds were pretreated with cold water for 8 hr. The determination of karyotype parameters was carried out using a MiniMop (Kontron) Image Analyzer, working with photomicrographs. Mean descriptive values of each karyotype were calculated from a minimum of five scattered metaphases measured from each species. The nomenclature used for the description of the chromosome morphology is that proposed by Levan et al. (1964). The $\mathrm{m}, \mathrm{sm}$, and st chromosomes are arranged in descending size. The SAT chromosomes were placed at the right end of the karyogram. To estimate karyotype asymmetry, two numerical parameters were used $\left(A_{1}\right.$ and $\left.A_{2}\right)$ according to Romero Zarco (1986).

DNA content: Root tip cells were fixed in $3: 1$ (absolute ethanol-acetic acid). The optimal hydrolysis time ( $\mathrm{HCL} 5 \mathrm{~N}, 20 \pm 2^{\circ} \mathrm{C}$ ) was $40 \mathrm{~min}$. Roots were stained in Feulgen for $90 \mathrm{~min}$ and were rinsed three times in $\mathrm{SO}_{2}$ water. Squashing was carried out in $45 \%$ acetic acid and the coverslip was removed after freezing with $\mathrm{CO}_{2}$. The material was dehydrated in absolute alcohol and mounted in euparal. The amount of Feulgen staining per nucleus, expressed in arbitrary units, was measured at a wavelength of $570 \mathrm{~nm}$, using a scanning method with a Zeiss Universal microphotometer (UMSP30). The DNA content per basic genome, expressed in picograms was calculated using Allium cepa as a standard $(2 \mathrm{C}=33.55 \mathrm{pg}$; Bennett and Smith 1976). Differences in DNA content were tested by analysis of variance (ANOVA) and comparison between means was performed using Scheffe's method.

\section{Results and discussion}

The six species presented here have three $(x=11, x=13$ and $x=14)$ of the seven basic numbers known in the genus. $A$. cruckshanksii has previously been reported to have $2 \mathrm{n}=26$, $2 \mathrm{n}=28$ and $2 \mathrm{n}=32$ in three different collections (Ledingham and Pepper 1973). These authors suggest that the $2 n=26$ count is probably an error resulting from the identification of one small pair of chromosomes as satellites while the $2 n=32$ count is understable since it is a common number in Old World species. In the collection here studied the $2 n=28$ count has been confirmed (Table 2, Fig. 1E). In $A$. pehuenches the chromosome number of $2 n=22$ reported by Ledingham and Pepper (1973) was confirmed (Fig. 1A). The chromosome numbers and karyotypes of the other species are reported for the first time.

The four species with $2 \mathrm{n}=28, \mathrm{x}=14$ (A. moyanoi, $A$. neuquenensis, $A$. cruckshanksii and $A$. illinii) have bimodal complements being st the largest chromosome. All four species possess satellites in the long arm of a median size chromosome (Table 2, Figs. 1, 2). The karyotypic similarity among these four species suggests a common ancestry. Ledingham and Pepper (1973) reported chromosome number of 30 species of South America Astragalus. These 
Table 2. Karyotypic formulae and asymmetry indeces $A_{1}$ and $A_{2}$

\begin{tabular}{lcccc}
\hline \hline Species & Karyotypic formulae & \multicolumn{2}{c}{ Asymmetry } & $\mathbf{A}_{1}$ \\
\hline A. pehuenches & $2 \mathrm{n}$ & $10 \mathrm{~m}+1 \mathrm{sm}$ & 0.23 & 0.24 \\
A. palenae var. grandiflora & 22 & $9 \mathrm{~m}+\quad+1 \mathrm{sm}$-st $+3 \mathrm{st}$ & 0.31 & 0.36 \\
A. moyanoi & 26 & $9 \mathrm{~m}+1 \mathrm{sm}+\quad+4 \mathrm{st}$ & 0.33 & 0.38 \\
A. neuquenensis & 28 & $7 \mathrm{~m}+5 \mathrm{sm}+\quad+2 \mathrm{st}$ & 0.34 & 0.33 \\
A. cruckshanksii & 28 & $5 \mathrm{~m}+6 \mathrm{sm}+1 \mathrm{sm}$-st $+2 \mathrm{st}$ & 0.34 & 0.42 \\
A. illinii & 28 & $9 \mathrm{~m}+1 \mathrm{sm}+\quad+3 \mathrm{st}+1 \mathrm{st}-\mathrm{t}$ & 0.34 & 0.35 \\
\hline
\end{tabular}

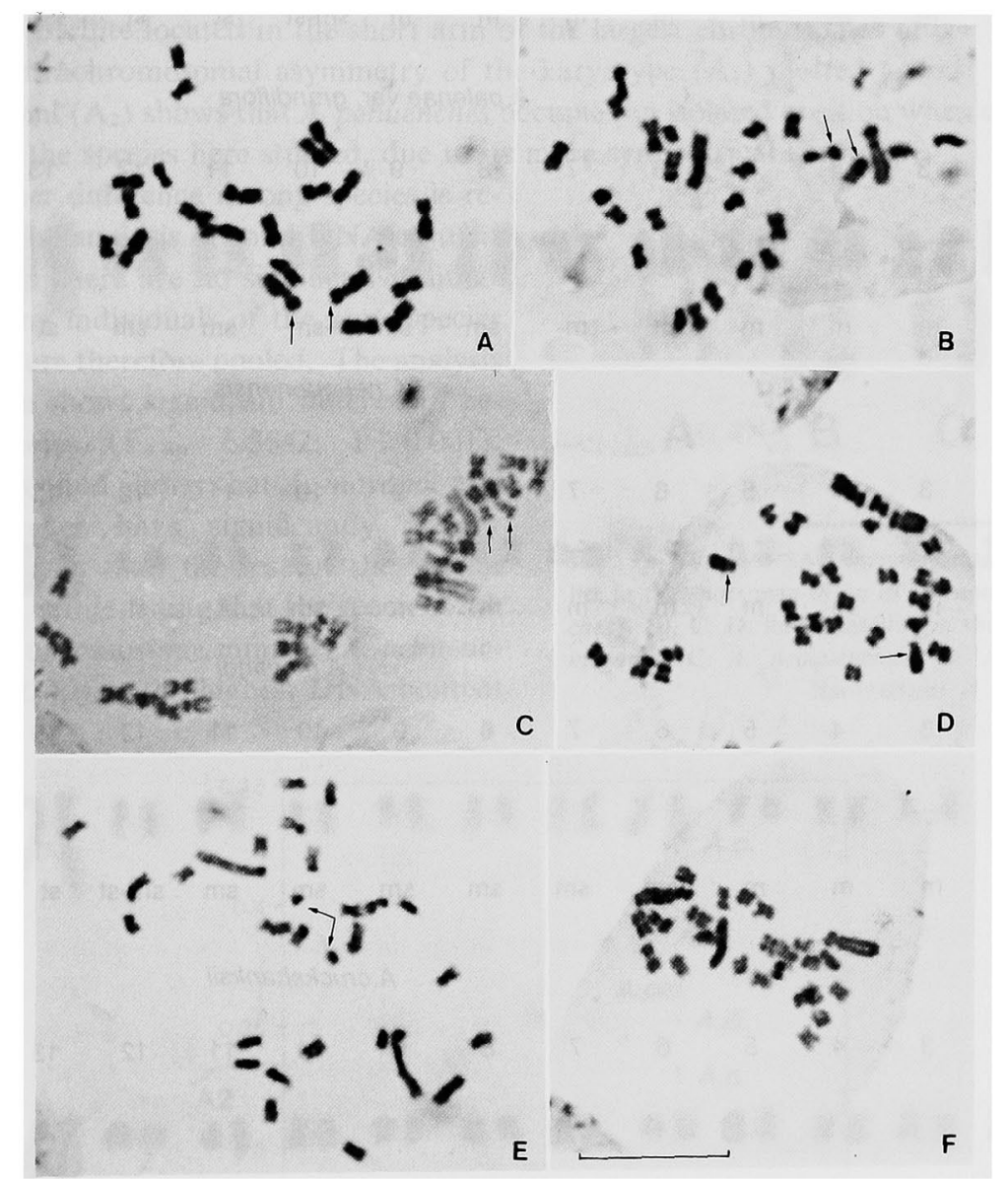

Fig. 1. Somatic metaphase cells. A: $A$. pehuenches, B: A. palenae var. grandiflora, C: $A$. neuquenensis, D: A. moyanoi, E: A. cruckshanskii, F: A. illinii. Arrows show SAT-chromosomes. $\mathrm{Bar}=10 \mu \mathrm{m}$.

authors do not indicate the exact morphology of chromosomes but they point out that "most of chromosomes are short, with arms more or less equal in length, but one pair is usually much longer".

A. palenae var. grandifiora has $2 \mathrm{n}=26$ chromosomes $(\mathrm{x}=13)$. Structural rearrangement may have changed the chromosome number and morphology but this is not readily detected. Karyotypic characteristics such as the bimodal karyotype (with the largest st chromosome), and satellites in the long arm of a median size chromosome, are maintained (Figs. 1B, 2). 

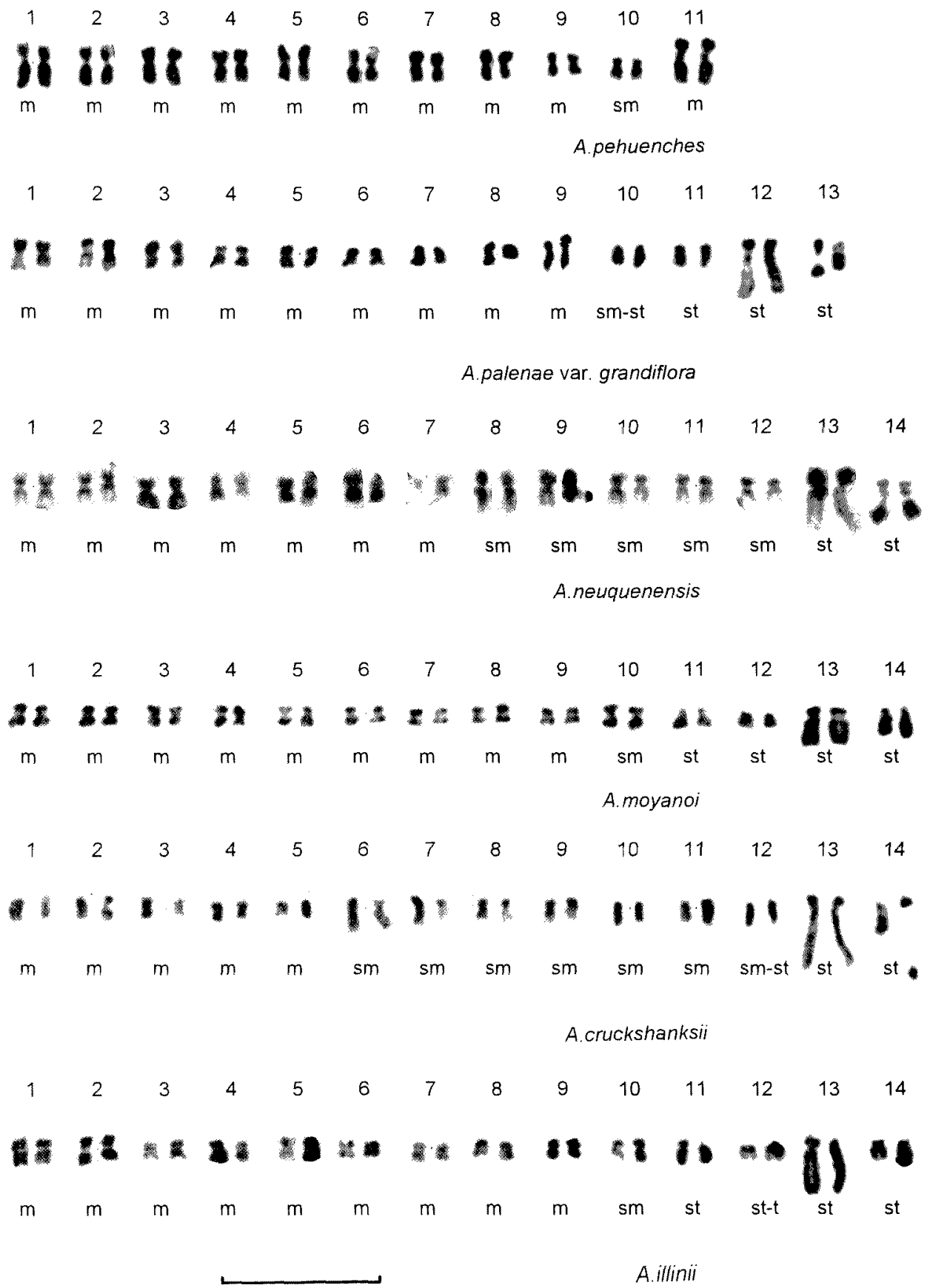

Fig. 2. Karyograms of the species of Astragalus. Bar $=10 \mu \mathrm{m}$.

Ledingham and Pepper (1973) reported that $n=13$ was the commonest number in the South American species they studied.

It is sometimes difficult to discriminate the primary and secondary constrictions. In Fig. 3, SAT chromosomes with elongated secondary constriction for several species are represented, demonstrating conclusively the location of the secondary constriction. The satellite represents 
$50 \%$ to $80 \%$ of the long arm, depending on the species.

Daviña and Gómez-Sosa (1993), reported the karyotypes of seven species from Argentina. These authors found species with $\mathrm{x}=11,12$ and 13 chromosomes, which have differences in their karyotypic formulae. They found a pair of SAT chromosome in the species studied but claimed that the satellites were always located on the short arms. These species belong to a separate morphological group from that studied in the present paper, with the exception of $A$. nelidae Gómez-Sosa, which have some similarities with $A$. palenae (Gómez-Sosa 1988). Both species have $2 n=26(x=13)$, bimodal karyotype with a largest st chromosome but differs in the position of the satellite.

$A$. pehuenches has a more symmetrical karyotype and a pair of SAT chromosomes with a prominent satellite located in the short arm of the largest chromosomes (Figs. 1A, 2, 4).

The intrachromosomal asymmetry of the karyotype $\left(A_{1}\right)$ plotted against that the interchromosomal $\left(\mathrm{A}_{2}\right)$ shows that $A$. pehuenches occupies an isolated position when compared with the rest of the species here studied, due to its more symmetrical karyotype.

Another difference among species is revealed by the analysis of total DNA content (Table 3). There are no significative differences among individuals of the same species and data were therefore pooled. The analysis of variance shows significant differences between species $\left(\mathrm{F}_{4,304}=6.3542 ; \mathrm{P}>0.001\right)$. Scheffe's method shows that $A$. moyanoi and $A$. pehuenches have significantly greater DNA contents than the rest of the species studied. It is interesting that the species with the lowest chromosome number, $A$. pehuenches $(2 n=22)$, has the highest DNA content

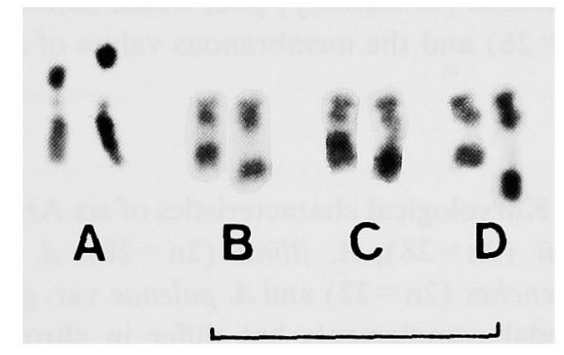

Fig. 3. Types of SAT-chromosomes. A: linear satellite in the short arm of an $\mathrm{m}$ chromosome (A. pehuenches). B, C, D: linear satellite in the long arm (B: $A$. moyanoi, C: A. neuquenensis, D: A. cruckshanksii). $\mathrm{Bar}=10 \mu \mathrm{m}$.

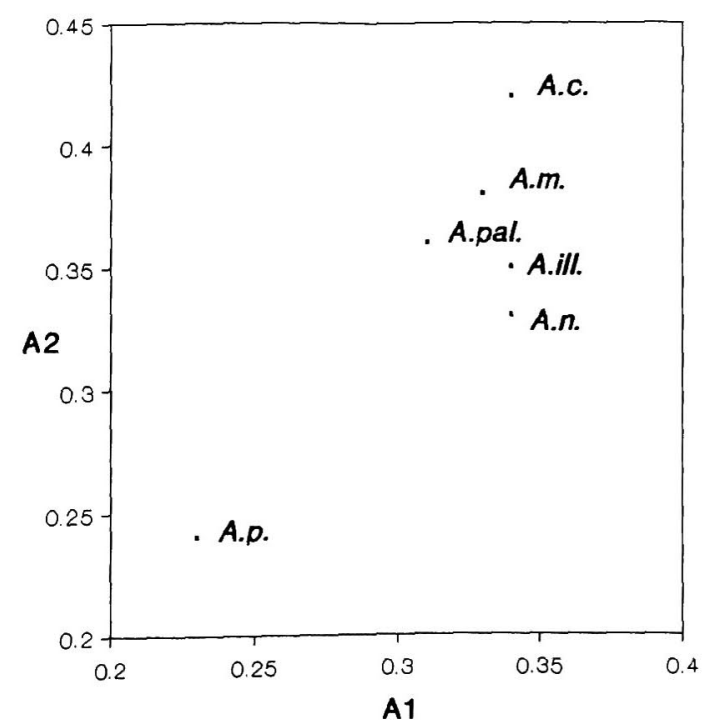

Fig. 4. Scatter diagram showing karyotype asymmetry indicated by the ratio between arm length $\left(\mathrm{A}_{1}\right)$ plotted against between total chromosome length $\left(\mathrm{A}_{2}\right)$. A.p. $=$ A. pehuenches, A.c. $=$ A. cruckshanksii, A.m. $=$ A. moyanoi, A.pal. $=A$. palenae var. grandiflora, A. ill. $=A$. illinii, A.n. $=$ 
Table 3. Total DNA content

\begin{tabular}{lccc}
\hline \hline Species & $2 \mathrm{n}$ & No. nuclei measured & $\begin{array}{c}\text { DNA content }(2 \mathrm{C}) \mathrm{pg} \\
\mathrm{X} \pm \mathrm{ES}^{2}\end{array}$ \\
\hline A. pehuenches & 22 & $74(4)$ & $3.65 \pm 0.07^{\mathrm{a}}$ \\
A. neuquenensis & 28 & $49(2)$ & $2.96 \pm 0.04^{\mathrm{c}}$ \\
A. moyanoi & 28 & $73(4)$ & $3.33 \pm 0.05^{\mathrm{b}}$ \\
A. cruckshanksii & 28 & $60(3)$ & $2.88 \pm 0.05^{\mathrm{c}}$ \\
A. illinii & 28 & $76(3)$ & $2.81 \pm 0.04^{\mathrm{c}}$ \\
\hline
\end{tabular}

${ }^{1}$ Number of replicates between brackets. ${ }^{2}$ Means with the same letter are not significantly different.

(Table 3). These data are in agreement with the isolated position that $A$. pehuenches occupies when asymmetry indices are considered (Fig. 4).

The members of species with $2 n=28$ studied in the present work are similar in both vegetative and reproductive morphology, indicating a close affinity. They have in common a coriaceous (or leathery) pod, which differs from the papery pods of $A$. palenae var. grandiflora $(2 \mathrm{n}=26)$ and the membranous valves of $A$. pehuenches $(2 \mathrm{n}=22)$.

\section{Summary}

Karyological characteristics of six Argentinian Astragalus species are reported: $A$. cruckshanksii $(2 \mathrm{n}=28)$, A. illinii $(2 \mathrm{n}=28), A$. neuquenensis $(2 \mathrm{n}=28), A$. moyanoi $(2 \mathrm{n}=28), A$. pehuenches $(2 \mathrm{n}=22)$ and $A$. palenae var. grandiflora $(2 \mathrm{n}=26)$. The $\mathrm{x}=13$ and 14 species have bimodal complements but differ in chromosome morphology and asymmetry indices. All species have a single pair of chromosomes with satellites located on the long arms. $A$. pehuenches $(2 \mathrm{n}=22, \mathrm{x}=11)$ has a more symmetrical karyotype and a pair of SAT chromosomes with a satellite located on the short arms. Among the species with $2 n=28, A$. moyanoi has significantly greater DNA content than the rest. The species with the lowest chromosome number, $A$. pehuenches, has the highest DNA content. The members of species with $2 n=28$ studied in the present work are similar in both vegetative and reproductive morphology.

\section{Acknowledgements}

This work was grant-aided by the Buenos Aires University and Argentine Research Council (CONICET, PID3319400-92). The authors are grateful to Prof. Dr. John S. Parker (Univ. of Reading, UK) for valuable suggestions on an earlier draft of this manuscript and to Prof. Dr. C. A. Naranjo for critical revision of the final manuscript. The second author (E.G$S$ ) is grateful to the Argentine Council (CONICET) for financial assistance used for field collections (Grant in Aid 6019636-91).

\section{References}

Ashraf, M. and Gohil, R. N. 1988. Studies on the cytology of legumes of Kashmir Himalaya. I. Cytology of Astragalus melanostachys Benth. ex Bunge with a new base number for the genus. Caryologia. Vol. 41, $\mathrm{n}^{\circ} 1: 61-67,1988$. Battaglia, E. 1955. Chromosome morphology and terminology. Caryologia 8: 179-187.

Bennett, M. D. and Smith, J. B. 1976. Nuclear DNA content in angiosperms. Proc. R. London Ser. B 274: $227-274$. Daviña, J. R. and Gómez-Sosa, E. 1993. Cariotipo de siete especies del género Astragalus (Leguminosae) de la Argentina. Bot. Soc. Argent. Bot. 29(3-4): 197-201.

Gómez-Sosa, E. 1979. Las especies sudamericanas del género Astragalus. (Leguminosae) I. Las especies patagónicas argentinas. Darwiniana 22(1-3): 313-376.

- 1984. Astragalus L. En Correa, M. N., Flora Patagónica, Col. Cientifica, INTA, Parte IVb Droseraceae a 
Leguminosae: $175-206$.

- 1988. Novedades en elugénero Astragalus, III (Leguminosae-Galegeae). Bol. Soc. Arg. Bot. 25(3-4): 485-493.

- 1994. Astragalus L. En Kiesling, R., Flora de San Juan, República Argentina, Vol. 1: 318-326. Ed. Vázquez Mazzini, Buenos Aires.

Ledingham, G. F. 1960. Chromosome numbers in Astragalus and Oxytropis. Canad. J. Genet, Cytol. 2(2): $119-128$.

- and Fahselt, M. D. 1964. Chromosome numbers of some north American species of Astragalus (Leguminosae) SIDA 1(6): 313-327.

- and Pepper, B. M. 1973. Chromosome numbers of some South American species of Astragalus. Kurtziana 7: 2737.

Levan, A., Fredga, K. and Sandberg, A. A. 1964. Nomenclature for centromeric position on chromosomes. Hereditas 52: $201-220$.

Romero Zarco, C. 1986. A new method for estimating karyotype asymmetry. Taxon 35: 526-530.

Spellenberg, R. 1976. Chromosome numbers and their cytotaxonomic significance for North American Astragalus (Fabaceae). Taxon 25(4): 463-476.

Wojciechowski, M. F., Sanderson, M. J., Baldwin, B. G. and Donoghue, M. J. 1993. Monophyly of aneuploid Astragalus (Fabaceae): evidence from nuclear ribosomal DNA internal transcribed spacer sequences. Am. J. Bot. 80(6): 711-722. 